\title{
Sex Hormone-Producing Adrenal Cortex Adenoma
}

National Cancer Institute

\section{Source}

National Cancer Institute. Sex Hormone-Producing Adrenal Cortex Adenoma. NCI

Thesaurus. Code C48452.

A rare adenoma of the adrenal cortex that produces androgens or estrogens. 